Annals of Warsaw University of Life Sciences - SGGW

Land Reclamation No 40, 2008: 77-86

(Ann. Warsaw Univ. of Life Sci. - SGGW, Land Reclam. 40, 2008)

\title{
The uncertainty of the water flow velocity data obtained in the laboratory test
}

\author{
EDYTA MALINOWSKA, WOJCIECH SAS, ALOJZY SZYMAŃSKI \\ Department of Geotechnical Engineering, Warsaw University of Life Sciences - SGGW
}

\begin{abstract}
The uncertainty of the water flow velocity data obtained in the laboratory test. Some of the engineering constructions are significant for the environment and flood protection. There are dams for water retention as well as waste tailings dams and road embankments founded on organic soils. Constructions on soft organic soils make it necessary to calculate subsoil deformations with a special regard of the water flow. In this thesis, the approach of the water flow test in soft organic soils is presented. In the permeability test the modern flow-pump technique was applied. This technique takes into consideration organic fiber structure, large soil strain, short time of research and "real" hydraulic gradients appearing in situ. The specific behavior of soft subsoil demands to calculate the test reliability results. Therefore in the statistical analysis of the test results the suitable statistical method and the proper laboratory technique should be used. Several statistical models have been applied to the flow pump test results in order to find the correct description of water flow velocity in soft subsoil.
\end{abstract}

Key words: organic soils, laboratory test, flow characteristics, data uncertainty.

\section{INTRODUCTION}

During construction and under loading in a long period of time the significant deformations of subsoil are observed (Szymański 1982, Lechowicz 1992). It gives rise to special problems connected with low soil strength and deformation parameters of organic subsoil and its loading by earth structures. The most obvious ones are large deformations that may occur during and after the construction period, both vertically and horizontally (Lechowicz and Szymański 1984). The consolidation process depends on distribution of water pore pressure, which is connected to permeability (Szymański 1991). The soft organic subsoil significantly changes the porosity during consolidation process, which causes the change of flow characteristics (Szymański et al. 2006). When the flow velocity of the pore water decreases substantially, consolidation process increases in time.

Consequently, the design, construction and maintenance of engineering constructions on organic soils should be preceded by the analysis of value and subsoil deformation course with special focus on nonlinear water flow characteristics (Szymański 1997, Malinowska 2005).

\section{LABORATORY TESTS}

The engineering peats assessment is very difficult because of lack of clear description for relations between individual parameters. The laboratory methods of permeability research used in geotechnics can be divided into three groups: both analytic and empiric 
estimations; numeral, mathematic and physics modelling and in situ or laboratory tests. In laboratory tests, indirect and direct techniques are applied.

Because of advantages such as a short time in which in-situ hydraulic gradients with the vertical effective stress control can be applied (Olsen 1966, Bartholomeeusen et al. 2001, Ing and Xiaoyan 2002, Malinowska et al. 2005), the modern direct flow-pump technique was used to characterize the water flow in peats under load (Fig. 1). soil located in Warsaw. The physical properties are presented in Table 1.

The proper description of water flow characteristics in organic soils is very important because of large amount of porosity, which can even reach the level of 80-90\% (Malinowska 2005).

In soft organic soils under the loading the soils spaces are completely saturated. Peats are characterized by large compressibility and deformation (Szymański 1997, Szymański and Sas 2001, Sas 2001). When the pore water

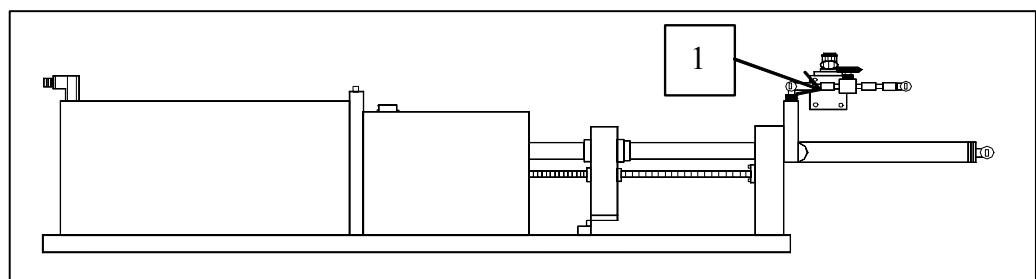

FIGURE 1. The flow-pump receiver, type VRDM 397/50 LWC: 1 - pressure differential sensor

In order to define the process of consolidation deformation, taking into account the nonlinear water flow characteristics in soft organic soils, the direct laboratory tests on peats samples taken from Campus SGGW site were done.

The laboratory deformation and flow pomp tests were performed on organic

TABLE 1. Physical properties of organic soils at Campus SGGW site

\begin{tabular}{|l|c|}
\hline Properties & Peat \\
\hline Water content $\mathrm{w}[\%]$ & $390-410$ \\
\hline Particle density $\rho_{\mathrm{s}}\left[\mathrm{g} / \mathrm{cm}^{3}\right]$ & 1.58 \\
\hline Bulk density $\rho\left[\mathrm{g} / \mathrm{cm}^{3}\right]$ & $1.00-1.40$ \\
\hline Dry density $\rho d\left[\mathrm{~g} / \mathrm{cm}^{3}\right]$ & $0.20-0.35$ \\
\hline Organic content IOM $[\%]$ & $60-80$ \\
\hline Degree of humification R $[\%]$ & $65-70$ \\
\hline
\end{tabular}

flow velocity in soil decreases remarkably, the consolidation process takes longer. The initial permeability in these soft organic soils is large, but decreasing with the value of compression. Figures 2 and 3 show the change of permeability in different consolidation conditions.

The test results show that the relationship between flow velocity and hydraulic gradient is nonlinear for the referred values of hydraulic gradient (Kany and Herman 1987, Bartholomeeusen et al. 2001, Hansbo 2001, 2003, Ing and Xiaoyan 2001, Malinowska 2005). For the small values of hydraulic gradient where the "prelinear filtration" is present, as showed on Figure 4 , the relationship is non-linear.

The results allowed to describe the relationship between the flow velocity, 


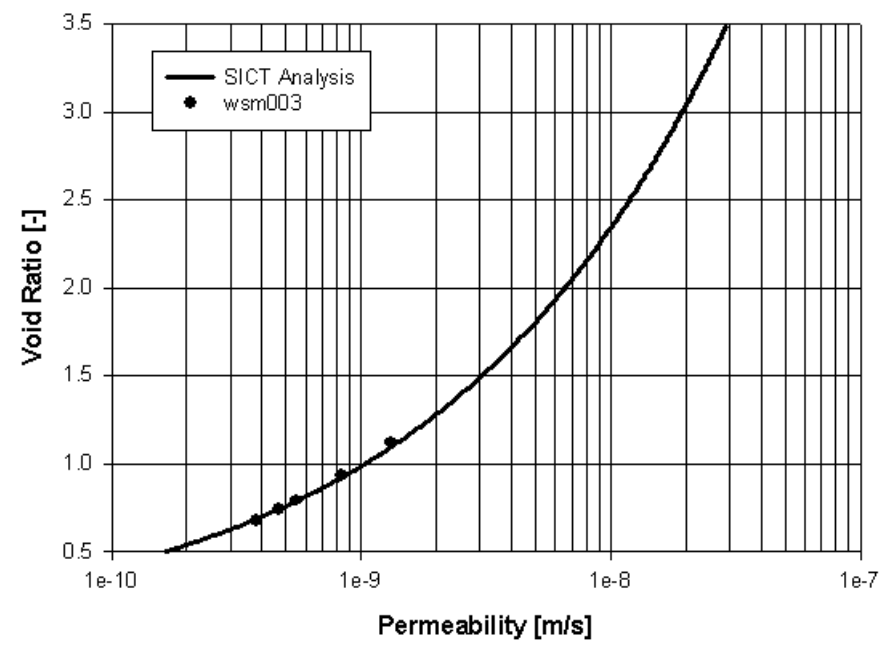

FIGURE 2. The laboratory test results made on clays. (Bartholomeeusen et al. 2001)

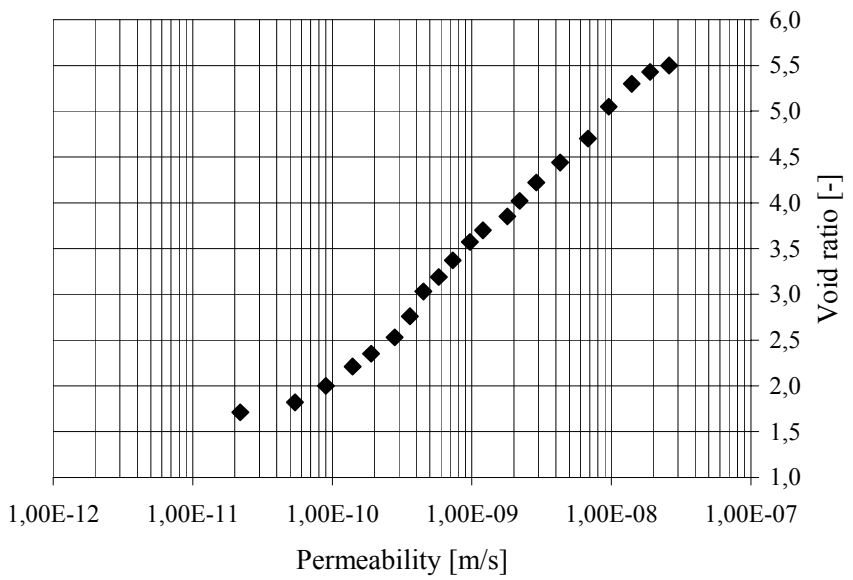

FIGURE 3. The laboratory test results made on peats (Malinowska et al. 2005, Malinowska 2005)

the hydraulic gradient and the void ratio, as the parameters with the highest range. The permeability characteristics were elaborated using statistic and the regression functions.

\section{STATISTICAL ESTIMATION METHOD}

The specifics of organic soils substratum calls for a series of repeated tests. The appropriate number of laboratory tests on representative soil samples sometimes cannot be met more than once because of the financial, time and technique limits. In order to elaborate the relationship, that correlates the best to datas obtained from the laboratory tests, several statistical methods have been applied.

The natural variability of the soft soil, the limitation of available datas, soil disturbance while testing, and 


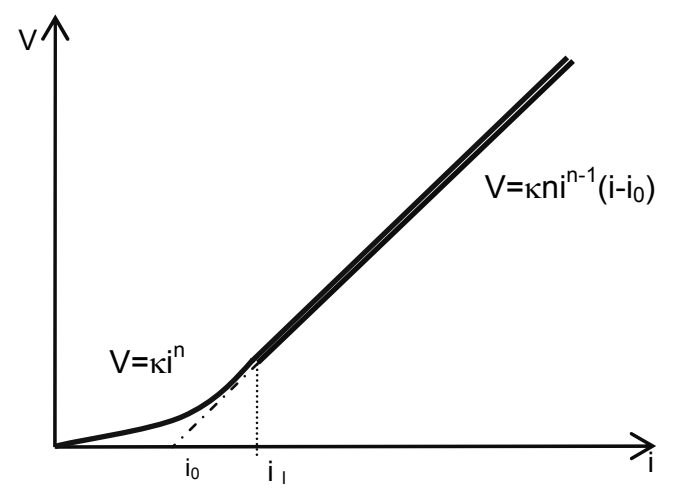

FIGURE 4. The laboratory test results tested on clays (Hansbo 2001)

measurements errors contribute the uncertainty of soil property evaluation. Parameters of a model were estimated by use of:

- Correlation coefficient - R,

- The mean relative error - MRE,

- Relative measures of deviations of modelled estimates from experimental data,

- Mean square relative deviation MSRD,

- Maximal relative deviation - MRD.

The measure of MSRD and MRE was used to evaluate model parameters by using Solver function in Excel Computer Programme.

For the analysis of uncertainty of hydraulic gradient test results (by flow-pump technique) and in order to evaluate the uncertainty of flow velocity data within soft soil samples, different values of loading are selected: $10,15,20,25$, 30,40 and $50 \mathrm{kPa}$.

Since it is difficult to perform tests strictly corresponding to requirements of uncertainty analysis, the value of extended uncertainty, $\mathbf{e}_{\mathbf{p}}$ is assessed by two estimates (Massoud 1999):

- $e_{p}{ }_{p}=1.96 \cdot s_{m}$ where $s_{m}$ is the value of mean standard deviation, $e_{p}$ ' neglects all between batch variations (based on measure of within batch variation) and

- $e^{\prime \prime}=1.96 \cdot s$

where $\mathrm{s}$ is the value of total standard deviation and $e_{p}$ " includes between batch variations (based on measure of total variation of data).

Interval estimation of uncertainty is done as followed:

- $e^{\prime}{ }_{p} \leq e_{p} \leq e^{\prime}{ }_{p}$

Uncertainty acceptability condition is assumed as:

- $e_{p} \leq e^{0}{ }_{p}$

where $e_{p}^{0}=0,15 \cdot \bar{X}$ and $\bar{X}$ is the value in the given set of data.

The analysis of uncertainty of the laboratory tests results of the flow characteristics in peats was carried out on the whole set of the laboratory tests results.

In Table 2, the comparison of the uncertainty analysis of some laboratory tests results is presented. Figure 5 shows the comparison of different coherence test results. 
TABLE 2. The comparison of the uncertainty analysis of the laboratory tests results

\begin{tabular}{|c|c|c|c|c|c|c|c|c|c|}
\hline \multirow{2}{*}{$\begin{array}{l}\text { Set's } \\
\text { order }\end{array}$} & \multicolumn{2}{|c|}{$\begin{array}{c}\text { The number of } \\
\text { analyzed sets }\end{array}$} & $\begin{array}{c}\text { Value of } \\
\text { load }\end{array}$ & \multicolumn{6}{|c|}{ The results of the uncertainty analysis } \\
\cline { 2 - 11 } & set A & set B & {$[\mathrm{kPa}]$} & $\mathrm{s}^{2}$ & $\mathrm{~s}$ & $\mathrm{r}$ & $\mathrm{e}_{\mathrm{p}}{ }^{\prime}$ & $\mathrm{e}_{\mathrm{p}}{ }^{\prime \prime}$ & $\mathrm{e}_{\mathrm{p}}$ \\
\hline 1 & 6.10 & 1.10 & 10 & 0.0068 & 0.0823 & 0.2305 & 0.1613 & 4.1180 & 0.4691 \\
\hline 2 & 6.10 & 11.10 & 10 & 0.0320 & 0.1788 & 0.5008 & 0.3505 & 4.0633 & 0.4754 \\
\hline 3 & 6.10 & 14.10 & 10 & 0.0232 & 0.1524 & 0.4268 & 0.2988 & 4.0839 & 0.4573 \\
\hline 4 & 11.10 & 14.10 & 10 & 0.0362 & 0.1904 & 0.5331 & 0.3731 & 3.9360 & 0.4892 \\
\hline 5 & 2.15 & 6.15 & 15 & 0.0318 & 0.1783 & 0.4992 & 0.3495 & 4.4213 & 0.5224 \\
\hline 6 & 5.20 & 11.20 & 20 & 0.0476 & 0.2181 & 0.6106 & 0.4274 & 4.5287 & 0.5093 \\
\hline 7 & 9.25 & 10.25 & 25 & 0.0726 & 0.2694 & 0.7544 & 0.5281 & 6.4834 & 0.6709 \\
\hline 8 & 2.30 & 6.30 & 30 & 0.1388 & 0.3725 & 1.0430 & 0.7301 & 10.5313 & 1.0934 \\
\hline 9 & 5.40 & 14.40 & 40 & 0.1509 & 0.3884 & 1.0876 & 0.7613 & 13.5101 & 1.3519 \\
\hline 10 & 9.50 & 10.50 & 50 & 10.289 & 3.2076 & 8.9813 & 6.2869 & 37.9758 & 7.1171 \\
\hline
\end{tabular}

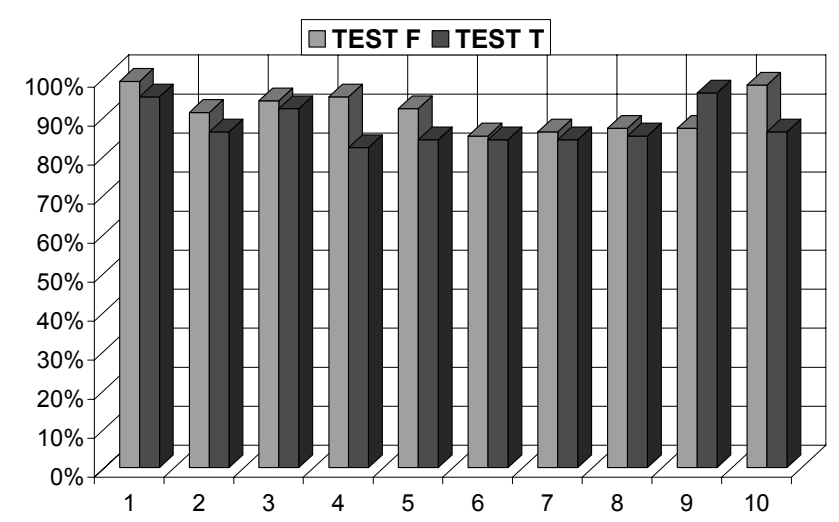

FIGURE 5. The comparison of different agreement test results

THE MEASUREMENT OF

UNCERTAINTY OF THE WATER FLOW VELOCITY DATA

The test results show that relationship between the flow velocity and the hydraulic gradient in soft organic peats is always nonlinear (Malinowska et al. 2005, Malinowska 2005) in the "prelinear filtration" area.

The results allowed describing the relationship between the flow velocity, the hydraulic gradient, and the void ratio as presented on Figure 6.

Because of the engineering properties of peat and also technique, time and financial limits of laboratory tests on the representative samples the design, construction and maintenance of engineering constructions on organic soils should be preceded by the analysis of value and subsoil deformation course with special focus on nonlinear water flow characteristics. 


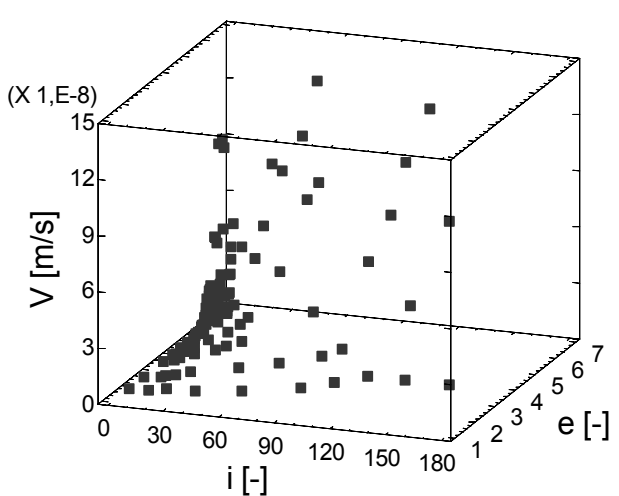

FIGURE 6. The laboratory test results made on peats (Malinowska et al. 2005, Malinowska 2005)

For that reason, the statistical analysis of the laboratory test results has to be received.

The lack of the clear relations between individual soft soils parameters makes the geotechnical assessment very difficult. The laboratory test results show strong relationship between the flow velocity, void ratio and hydraulic gradient. Several statistical correlation functions have been applied to the flow pump test datas in order to obtain the correct description of the water flow velocity in soft subsoils. The statistical analysis was aimed at identifying the model which fits as close as possible to the in situ values.

For practical purposes it is important to simplify the multiple regression function of many variables, eg.: strain $=\mathrm{f}$ (consolidation stress, deviatory stress, mean stress, void ratio, time etc.).

There were several models used to describe the best correlation.

- The linear model of the form:

$V=A \cdot i+B \cdot e$
$V=A \cdot i+B \cdot e+C$

- The non-linear models of the form as followed:

$V=A \cdot i^{B}+C \cdot e^{D}$

$V=A \cdot i^{B} \cdot e^{C}$

$V=A \cdot \exp (B \cdot i+C \cdot e)$

$V=A \cdot i^{3}+B \cdot e^{2}+C \cdot i \cdot e$

$V=A \cdot i^{4}+B \cdot e^{3}+C \cdot i^{2} \cdot e+D \cdot i \cdot$

$\cdot e^{2}+F \cdot i \cdot e$

where:

$V$ - variable being modelled, which is predicted value of flow velocity

$i$ - the value of the hydraulic gradient, $e$ - the value of void ratio,

$A, B, C, D, F$ - empirical coefficients.

The multiple nonlinear regression method was applied to identify the empirical coefficients and estimate the reliability. As the adaptation measurement, the minimization of the mean square relative deviation (MSRD) and the mean square error (MRE) was accepted. The comparison of analyzed models of the flow velocity for tested soft soils is showed in Table 3.

The best correlation for nonlinear model is showed as an equation 8. In this model there are only two unknown empirical coefficient, and two measured parameters: $i$ - hydraulic gradient and $e$-void ratio. Nevertheless the influence of other parameters should be considered (f.e. temperature, sample cubature, time).

The exemplary surfaces of loaded soft soil, considering the relationship between the flow velocity, void ratio and hydraulic gradient, are showed on Figure 7. 


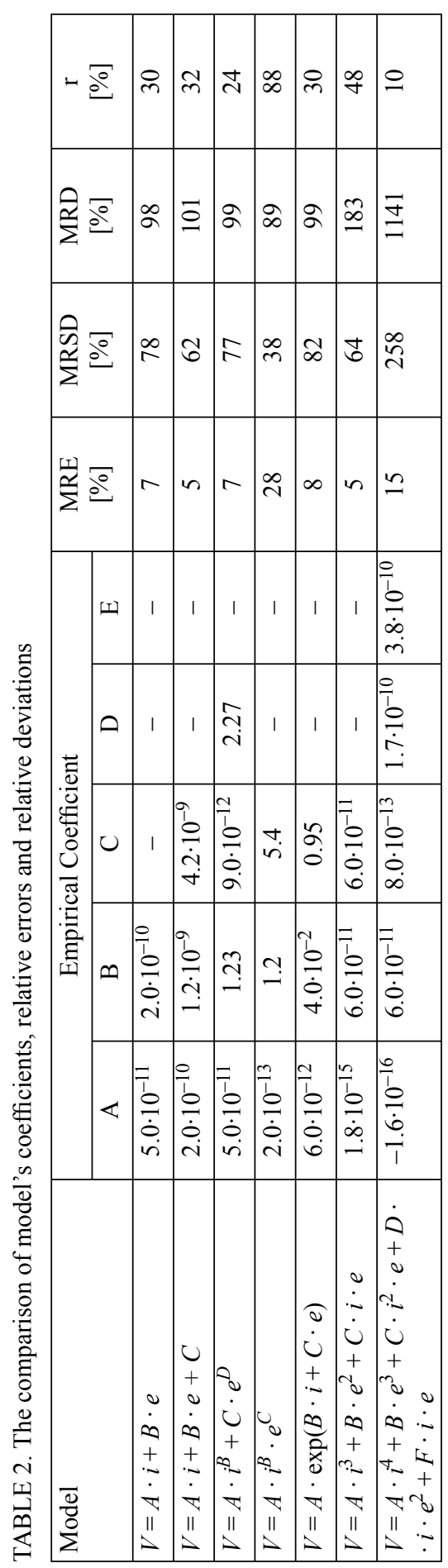

\section{SUMMARY}

The lack of clear description for relations between soft sols individual parameters makes it quite difficult to assess the engineering peats behaviour under loading. Because of large deformations and a very large content of water in the porous organic subsoil, the design, construction and maintenance of engineering constructions on organic soils should be preceded by the analysis of deformations with the special focus on nonlinear water flow characteristics.

In the statistic analysis of the laboratory tests, done by the flow-pump technique, the flow velocity depends on the "real" in situ hydraulic gradient and void ratio. Hence, in the statistical analysis of the laboratory test results, the required measurement adaptation, the reliability opinion, and the uncertainty analysis should be done.

In order to elaborate on the above-mentioned relationship, the appropriate number of laboratory tests on representative soil samples has to be done. Because of the financial, time and technique limits such repetition often can not be caused more than once. That's why it is important to find a model which would be the most closely correlated to the results obtained in the laboratory test.

The analysis of the uncertainty of the laboratory tests results, based on widely used statistical methods, show that uncertainty acceptability condition is within the $15 \%$ of hesitation.

Also the laboratory test results show strong relationship between the flow velocity, void ratio, and hydraulic gradient. Analysis of several models 
a

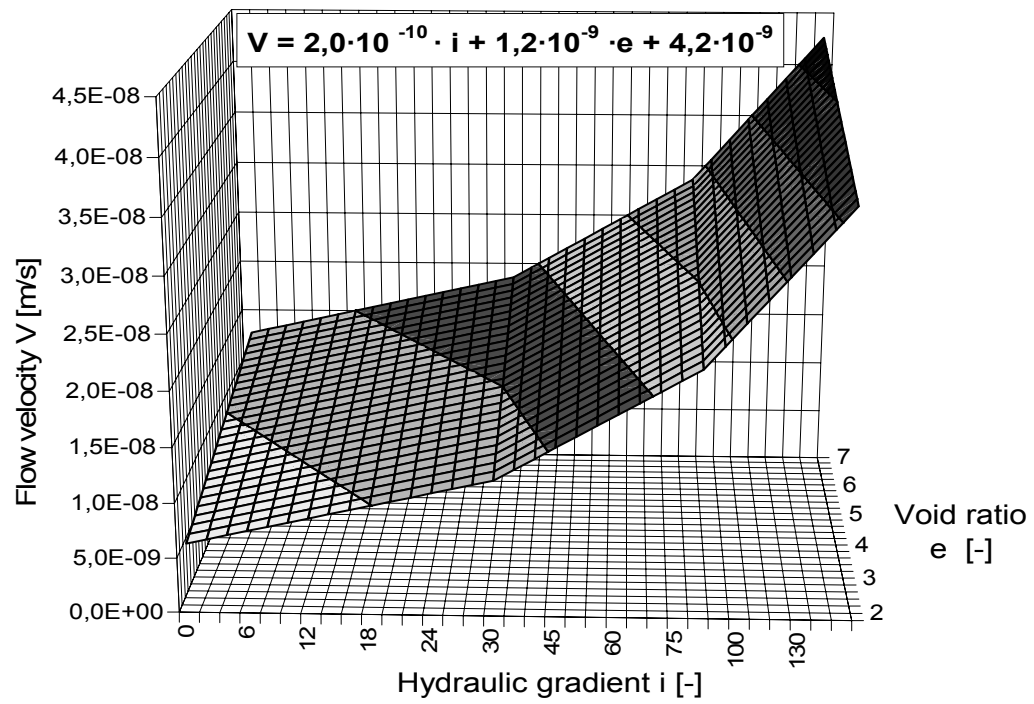

b

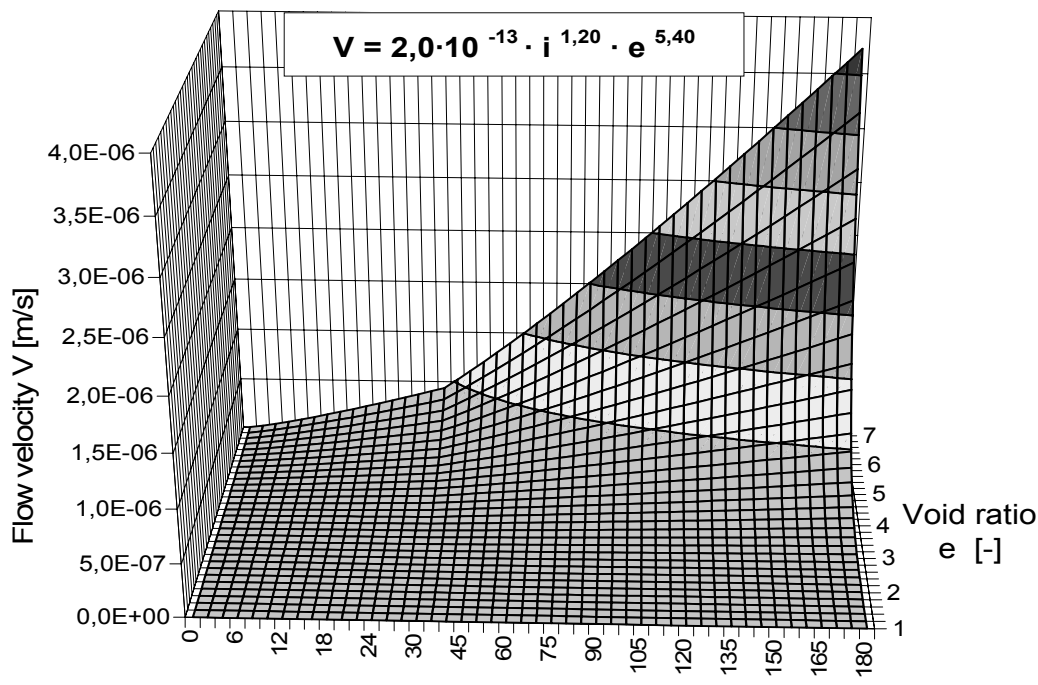

Hydraulic gradient i [-]

FIGURE 7. Example of a model describing the relationship between the flow velocities, void ratio and hydraulic gradient: a) linear model, b) - nonlinear model

applied to the flow pump test data show that the best correlation is given by the nonlinear model of the following form:

$\mathrm{V}=2.0 \cdot 10^{-13} \cdot \mathrm{i}^{1.2} \cdot \mathrm{e}^{5.4}$
The mean relative error of this model is on the level of $28 \%$, the mean square relative deviation is on the level of $38 \%$, the maximal relative deviation is on the level of $89 \%$ and the correlation 
coefficient is on the level of $88 \%$. The statistical analysis was made to evaluate the model that fits as close as possible to the in situ values.

For practical purposes it is important to simplify the multiple regression function of many variables.

The analysis of uncertainty of the laboratory test results in the flow characteristics in the peats was carried out on the whole set of the laboratory test results. The agreement tests give the following concurrences of the test results:

- TEST F: $83 \%-99 \%$

- TEST T: $82 \%-98 \%$.

The analysis of uncertainty of the laboratory test results shows that the flow-pump researches, in which the hydraulic gradient is measured in and out of the soil sample, were done properly.

\section{REFERENCES}

BARTHOLOMEEUSEN G., ZNIDARCIC D., HWANG CH., SILLS G.C. 2001: Seepage Inducted Consolidation Test. University of Colorado, UK, www-civil. eng.ox.ac.uk

HANSBO S. 2001: Consolidation equation valid for both Darcian and non-Darcian flow. Geotechnique 51, No 1, p. 51-54.

HANSBO S. 2003: Deviation from Darcy's law observed in one-dimensional consolidation. Geotechnique 53, No 6, pp. 601-605, 2003.

ING T.C, XIAOYAN N. 2002: Coupled consolidation theory with non-Darcian flow. Computers and Geotechnics 29. School of CSE, Nanyang Technological University, Singapore, p. 169-210.

KANY M., HERRMANN R. 1987: Water motion in soils based on a diffusion theory of mixtures (part 2). Proc. of the 9th Europ. Conf. on Soil Mech. and Found. Eng. Dublin.

LECHOWICZ Z. 1992: Ocena wzmocnienia gruntów organicznych obciążonych nasypem. Monographic. Wyd. SGGW. No 162.

LECHOWICZ Z., SZYMAŃSKI A. 1984: Prediction of consolidation of organic soil. Annals of Warsaw Agricultural University, No 20, p. 55-59.

MALINOWSKA E., 2005: Analiza odkształceń wybranych gruntów organicznych organicznych uwzględnieniem nieliniowych charakterystyk przepływu. (In Polish.) The description of soft soils deformations using the nonlinear characteristic of water flow. Doctor's thesis, Warsaw Agricultural University.

MALINOWSKA E., SZYMAŃSKI A., SAS W. 2005: Wyznaczanie charakterystyk przepływu wody w gruntach organicznych metodą flow-pump. (In Polish). Determination of water flow characteristics in organic soils by the flow-pump technique. Przeglad Naukowy Inżynierii i Kształtowania Środowiska. Vol 1 (31), p. 114-121.

MASSOUD FARAG MASSOUD 1999: The use of cone penetration test for determination of mechanical parameters of cohesive silos. Doctor's thesis, Warsaw Agricultural University.

OLSEN H.W. 1966: Darcy's Law in Saturated Kaolinite, Water Resources Research. Vol. 2, No 6, 287-295.

SAS W. 2001: Modelowanie odkształceń gruntów organicznych z uwzględnieniem zmian właściwości ośrodka. (In Polish.) The modelling of deformation process of organic silos including changes in porous media. Rozprawa doktorska - SGGW, Warszawa.

SZYMAŃSKI A. 1982: Charakterystyki procesu odkształcenia pod obciążeniem wybranych rodzajów torfów. (In Polish.) Deformation characteristics of selected kind of peats under loading. Doctoral's thesis. SGGW - AR, Warsaw. 
SZYMAŃSKI A. 1991: Czynniki warunkujące analizę odkształcenia gruntów organicznych obciążonych nasypem. (In Polish.) The factors determining the deformations analysis of organic subsoil inder embankment. Habilitation's treaties. SGGW-AR, Warsaw.

SZYMAŃSKI A. 1997: Numerical analysis of consolidation performance in layered soft subsoil. Conf. On Recent Advances in Soft Soil Engineering. Malaysia. Kuching: 230-241.

SZYMAŃSKIA., SAS W. 2001: Deformation characteristics of organic soils. Ann. of Warsaw Agricult. Univ. - Land Recl. 32, p. 117-126.

SZYMAŃSKI A., SAS W., DROŻDŻ A., MALINOWSKA E. 2006: Soft subsoil improvement and factors which determine the consolidation. XIII Danube - European Conference on Geotechnical Engineering. Ljubljana - Słowenia.

Streszczenie: Miara niepewności wyników pomiarów uzyskanych z badań laboratoryjnych przeptywu. W artykule przedstawiono wyniki miary niepewności pomiarów uzyskanych $\mathrm{z}$ ba- dań laboratoryjnych parametrów przepływu przez słabonośne podłoże organiczne. Uzyskiwane w laboratorium zależności parametrów przepływu od wskaźnika porowatości i zastosowanego obciążenia konsolidacyjnego wskazują na nieliniowość charakterystyk przepływu. Celem sprawdzenia wiarygodności otrzymywanych z badań laboratoryjnych wyników i możliwości wykorzystania ich przy wyznaczaniu charakterystyk przepływu odgrywających bardzo ważną rolę w procesie odkształceń konsolidacyjnych została przeprowadzona ocena niepewności wyników pomiarów różnicy ciśnień i wskaźnika porowatości. $\mathrm{Na}$ podstawie przedstawionych obliczeń oceny niepewności wyników pomiarów stwierdzono, że pomiary różnicy ciśnień na wejściu i wyjściu z próbki gruntu techniką kontrolowanego przepływu (flow-pump) zostały wykonane prawidłowo, a powtarzalność pomiarów jest zadowalająca.

\author{
Authors' address: \\ Katedra Geoinżynierii \\ Wydział Inżynierii i Kształtowania Środowiska \\ SGGW \\ Nowoursynowska St. 166 \\ 02-787 Warszawa \\ Poland.
}

